\title{
THEORY AND PRACTICE OF PROJECT MANAGEMENT OF WATERWORKS
}

\section{Lapkina I. O., Kryzhanovska I. P.}

\section{INTRODUCTION}

For the development of water transport in Ukraine, one of the main factors is the state of the most important transport infrastructure components such as waterways and waterworks.

Seaports are the link between sea and land transport. To be able to ensure their purpose, ports must have facilities that meet the requirements of different means of transport, be equipped with powerful transshipment equipment, as well as have modern routes from both sea and land.

The National Transport Strategy of Ukraine for the period up to $2030^{1}$ notes that there are 13 seaports in the Black Sea-Azov Basin and the Danube Delta in Ukraine, with a total cargo handling capacity of more than 230 million tons per year.

As emphasized in the document, the implementation of the "Strategy" provides for the implementation of tasks in the main areas, including: "competitive and efficient transport system; innovative development of the transport sector and global investment projects.

Most of the investment funds for infrastructure improvement are expected from external sources, primarily from international financial institutions, private investors and public-private partnership projects. Attracting investment funds from such sources in innovative transport projects is a condition for the development of not only the transport industry, but also the national security and competitiveness of the country".

The "Strategy" also identifies common issues that need to be addressed. These include the following: lack of funding for the transport sector, low level of resource management and lack of measures for stable development of transport enterprises, high level of depreciation of fixed assets, technological backwardness of transport and infrastructure, low

${ }^{1}$ Про схвалення Національної транспортної стратегії України на період до 2030 p. URL: https://zakon.rada.gov.ua/laws/show/430-2018-\%D1\%80\#Text. 
level of introduction of modern technologies and implementation of innovation policy in the transport sector.

An important dimensional characteristic is the length of the berth front. Analysis of the overall dimensions of berths to some extent can give a quantitative description of the moral operation. The depth near the border is the most significant in this respect, as the latter is due to the component of the water transport process, which is most quickly updated by the fleet (Table 1).

Table 1

\section{The structure of the berth front at depths} in the ports of some countries

\begin{tabular}{|c|c|c|c|c|c|c|c|}
\hline \multirow{2}{*}{$\begin{array}{c}\text { Depth of } \\
\text { water near } \\
\text { the berth, m }\end{array}$} & \multicolumn{7}{|c|}{ Percentage of berths in countries } \\
\cline { 2 - 8 } & Japan & China & France & $\begin{array}{c}\text { The } \\
\text { Netherlands }\end{array}$ & $\begin{array}{c}\text { The } \\
\text { USA }\end{array}$ & Russia & Ukraine \\
\hline $5,0-9,0$ & 30 & 30 & 40 & 29 & 38 & 30 & 26 \\
\hline $9-12,2$ & 35 & 34 & 31 & 31 & 50 & 57 & 56 \\
\hline $12,2-15,2$ & 14 & 18 & 14 & 21 & 5 & 8 & 6 \\
\hline $15,2-18,3$ & 14 & 10 & 8 & 11 & 5 & 5 & 3 \\
\hline $\begin{array}{c}\text { More than } \\
18.3\end{array}$ & 7 & 8 & 7 & 8 & 2 & 5 & 0 \\
\hline
\end{tabular}

In the direction of modernization of river transport infrastructure and infrastructure of deep-sea seaports, the results of providing actual depths in seaports and approach channels in accordance with the established passport characteristics, development of deep-sea seaports, including their waterworks, etc. are expected. Considering another criterion, i.e. the technical equipment of the berth front of the country's seaports, it should be noted that as of 2017, much of the transshipment equipment could be attributed to low-productivity and obsolete (usually cyclical mechanisms). The installation of more advanced technological equipment on berths, as a rule, requires the search for reserves of the berth front bearing capacity and, in many cases, necessitates repair or reconstruction measures.

"The Strategy for the development of seaports of Ukraine for the period up to $2038^{\prime \prime 2}$ provides for the creation of facilities for processing in seaports at least 250 million tons of cargo per year and ensuring effective development of port infrastructure, introduction of innovative activities by

${ }^{2}$ Про затвердження Стратегії розвитку морських портів України на період до 2038 p. URL: https://zakon.rada.gov.ua/laws/show/548-2013-\%D1\%80\#Text. 
seaports through the use of new technologies, increase to 75-80 percent of efficiency of use of transshipment complexes of seaports.

\section{Methodological basics of management of infrastructure projects of seaports}

At present the total length of cargo berths of seaports of Ukraine is about $34 \mathrm{~km}$, including the Danube region - 6,9 km, the Black Sea $21,7 \mathrm{~km}$, the Azov Sea - 5,6 km. Over the years, starting from the second half of the twentieth century, the berth front has increased in two directions: due to the reconstruction of existing ports and quays of the old structure and due to the construction of new ports including the two largest ports - Chornomorsk city and Southern city, the creation of which fell on this particular period. Construction of new and repeated reconstruction of existing ports ensured the availability of loading and unloading facilities, which mainly meet the needs of the country. However, 30-35\% of the berth front are in unsatisfactory condition and need reconstruction, technical re-equipment and overhaul. At present, the number of berths of the old fund in Ukraine is $35 \%$ of all existing berths, which forms the basis for the possibility of introducing innovative technologies and new materials, to increase carrying capacity and, accordingly, increase cargo turnover.

Proper functioning of seaports, maintenance and use of state-owned port infrastructure facilities, including modernization, repair, reconstruction and construction of waterworks, other port infrastructure facilities located within the territory and waters of seaports, is provided by the state enterprise "Ukrainian Sea Ports Authority" (USPA) $)^{3}$ ).

The USPA is a state unitary enterprise and operates as a state commercial enterprise in accordance with the Law of Ukraine "On Seaports of Ukraine" ${ }^{4}$, the order of the Cabinet of Ministers of Ukraine of March 4, 2013 №133 “On approval of proposals for reorganization of state enterprises of maritime transport" and belongs to the sphere of management of the Ministry of Infrastructure of Ukraine ${ }^{5}$.

3 Про затвердження політики власності державного підприємства «Адміністрація морських портів України». URL: https://mtu.gov.ua/files/Dok NORMATUVKA/643.pdf.

4 Закон України «Про морські порти України». URL: https:// zakon.rada.gov.ua/laws/show/4709-17.

5 Про погодження пропозицій щодо реорганізації державних підприємств морського транспорту. URL: https://zakon.rada.gov.ua/laws/show/133-2013$\% \mathrm{D} 1 \% 80$. 
The main goals of the USPA are commercial and non-commercial. Commercial purposes include the provision of services to vessels on approaches and directly in the waters of seaports. Non-profit, among others, first of all, should include the maintenance and effective use of state property, including modernization, repair, reconstruction and construction of waterworks and other port infrastructure; organization and ensuring safe operation of state-owned port infrastructure facilities, including waterworks, maritime safety systems located within the territory and waters of the seaport.

"The Strategic development plan of the USPA for the period up to $2025 " 6$ involves the development of modern and effective management tools; taking responsibility for the coordination and planning of territories within ports in a more efficient way; improving the maintenance of existing and developing new modern infrastructure; promoting the participation of the private sector in the development of port infrastructure. To this end, the portfolio of investment infrastructure projects will be updated on an ongoing basis for implementation with external sources of financing, in particular, with the involvement of private investors, credit resources of international financial organizations in the manner prescribed by law.

The implementation of "the Strategic Plan" should increase the competitiveness of seaports and help attract investment, including from the private sector to modernize port infrastructure. The following expected results on increasing the efficiency of cargo handling in Ukrainian ports and increasing the volume of transshipment per meter of berth for cargo types have been declared.

For general and bulk cargoes about 3,000 tons per meter of berth in 2025 , and to achieve the world average of 8,000 tons will require additional ten years and modernization of terminal capacity. Container handling will increase by at least $30 \%$ (up to 460 TEU per berth meter), but without additional measures Ukrainian ports will not be able to reach the global figure of $2000 \mathrm{TEU}$ in the optimistic scenario of 2030. For bulk cargo, handling will increase by about $10 \% 3500$ tons per meter of berth) and will reach 3800 tons in 2030. The total increase will be $10.5 \%$ comparing 2025 to 2020 .

Modern management tools widely use the methodology of management of infrastructure projects of seaports, including modernization,

6 Стратегічний план розвитку АМПУ на період до 2025 p. URL: http://www.uspa.gov.ua/pro-pidpriemstvo/strategichnij-plan-rozvitku. 
repair, reconstruction and construction of waterworks (Fig. 1). This involves the consistent application of the project approach for:

- monitoring the quality of seaport infrastructure on a regular basis;

- introduction of a mechanism for dynamic renewal of the project portfolio;

- goal setting and substantiation of projects that correspond to the strategic development plan;

- selection of future infrastructure projects;

- formation of a portfolio of infrastructure projects;

- ensuring the priority of projects in the portfolio on the basis of clearly defined criteria;

- initiation of projects and attraction of external financial resources, in particular signing of credit agreements and attraction of credit resources of the international financial organizations, private investors in the manner prescribed by law;

- application of resource and risk management methods in projects;

- increasing the economic efficiency of projects and reducing the time of their implementation (Fig. 2).

In accordance with the order of the Ministry of Infrastructure of Ukraine № 91 of February 18, 2013 "On approval of the Procedure for maintaining the Register of waterworks of seaports of Ukraine" in order to organize proper accounting and control of waterworks located in seaports of Ukraine, an electronic database was launched, which includes information on the use, specialization, technical characteristics and technical condition of waterworks. The holder of the Register is the Ministry of Infrastructure of Ukraine. The register is maintained in electronic form according to the form established ${ }^{7}$ and is the basis for continuous monitoring of waterworks.

Areas of work of the technical department of the Seaport Administration are: supervision, inspection, maintenance, construction (waterworks); construction and supervision of coastal facilities, maintenance and inspection; organization of technical construction projects; maintenance of computer equipment and software, etc.

7 Про затвердження Порядку ведення Реєстру гідротехнічних споруд морських портів України. URL: https://zakon.rada.gov.ua/laws/show/z036313\#n13. 


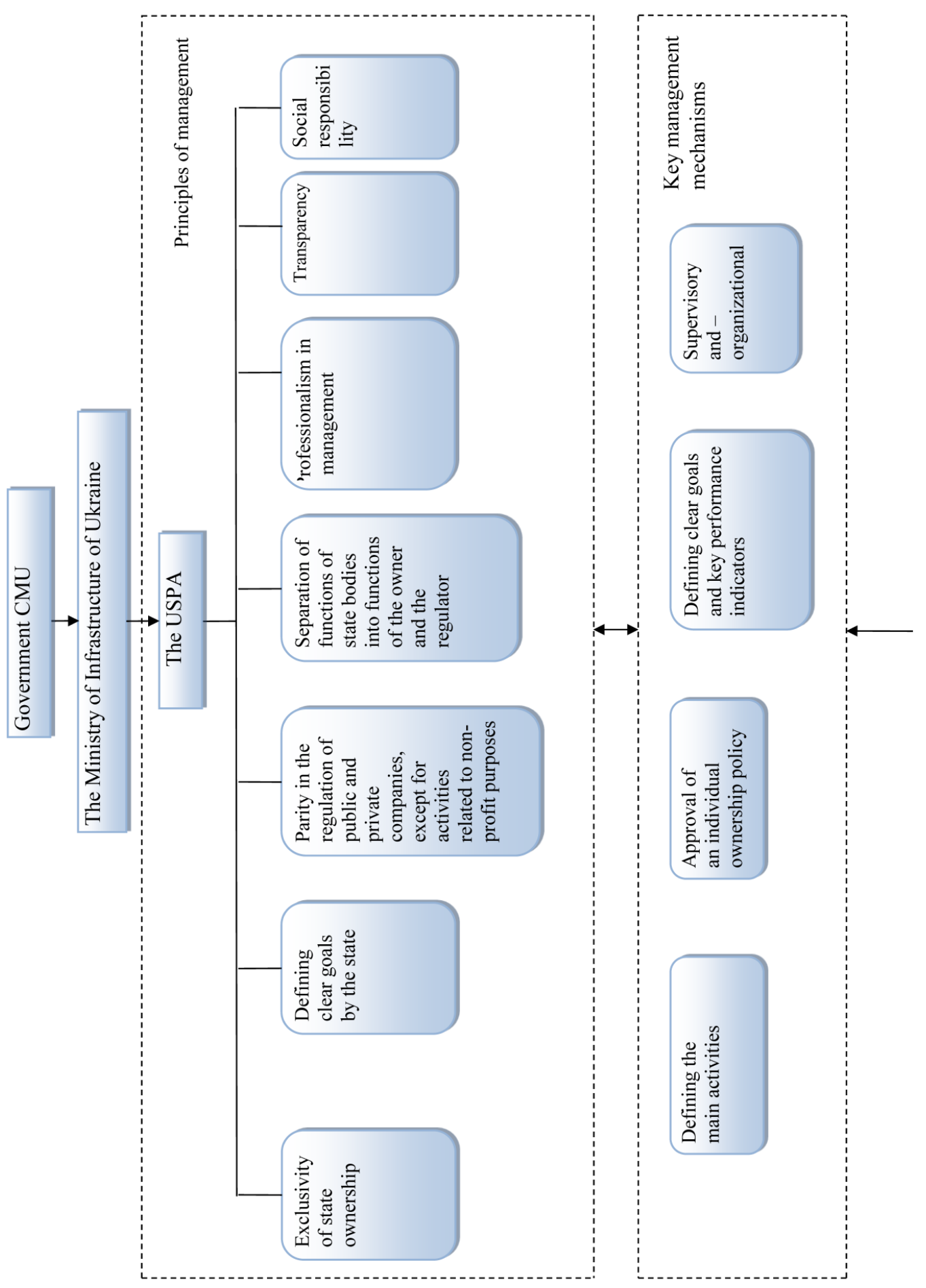




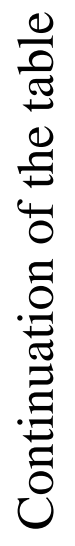

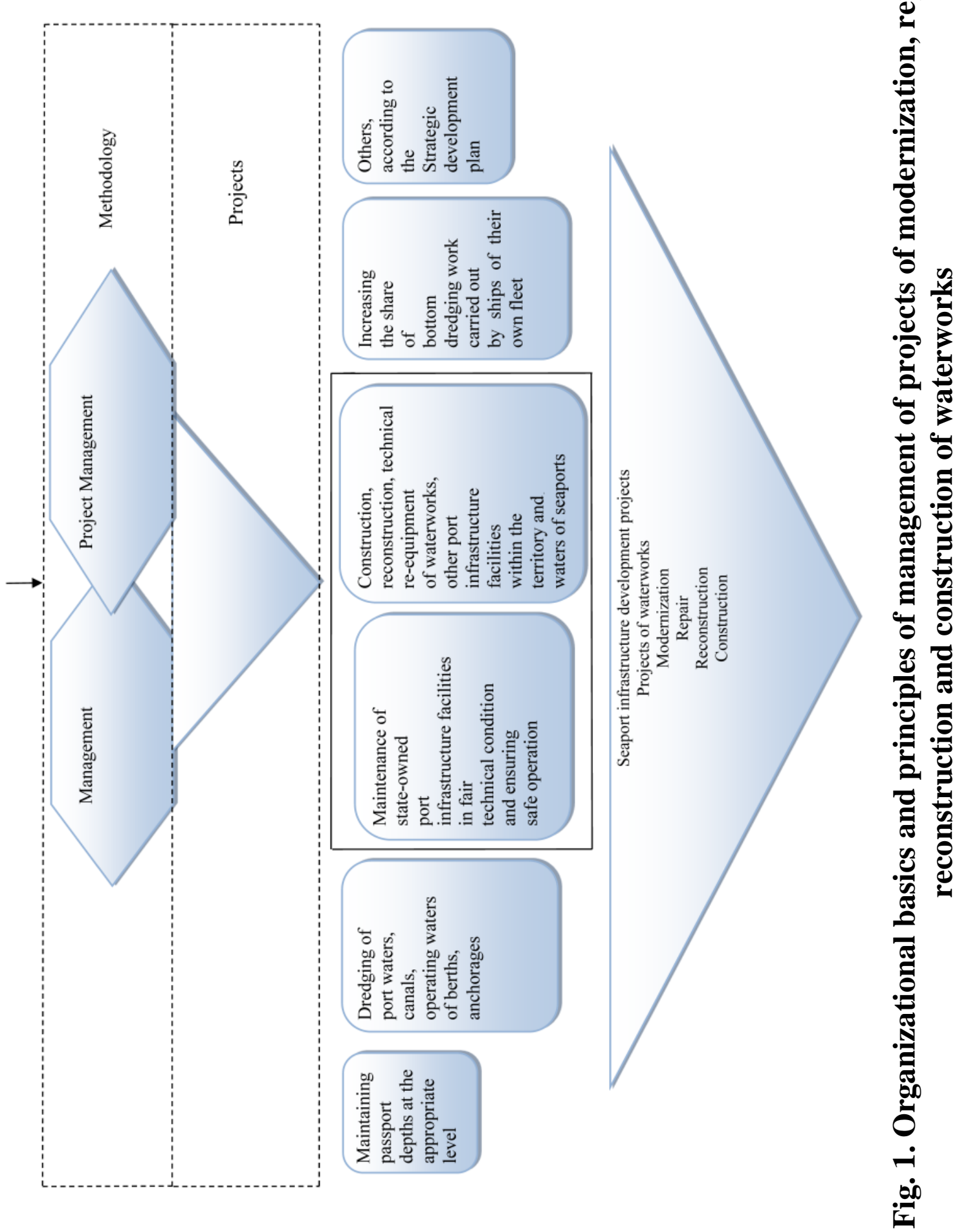




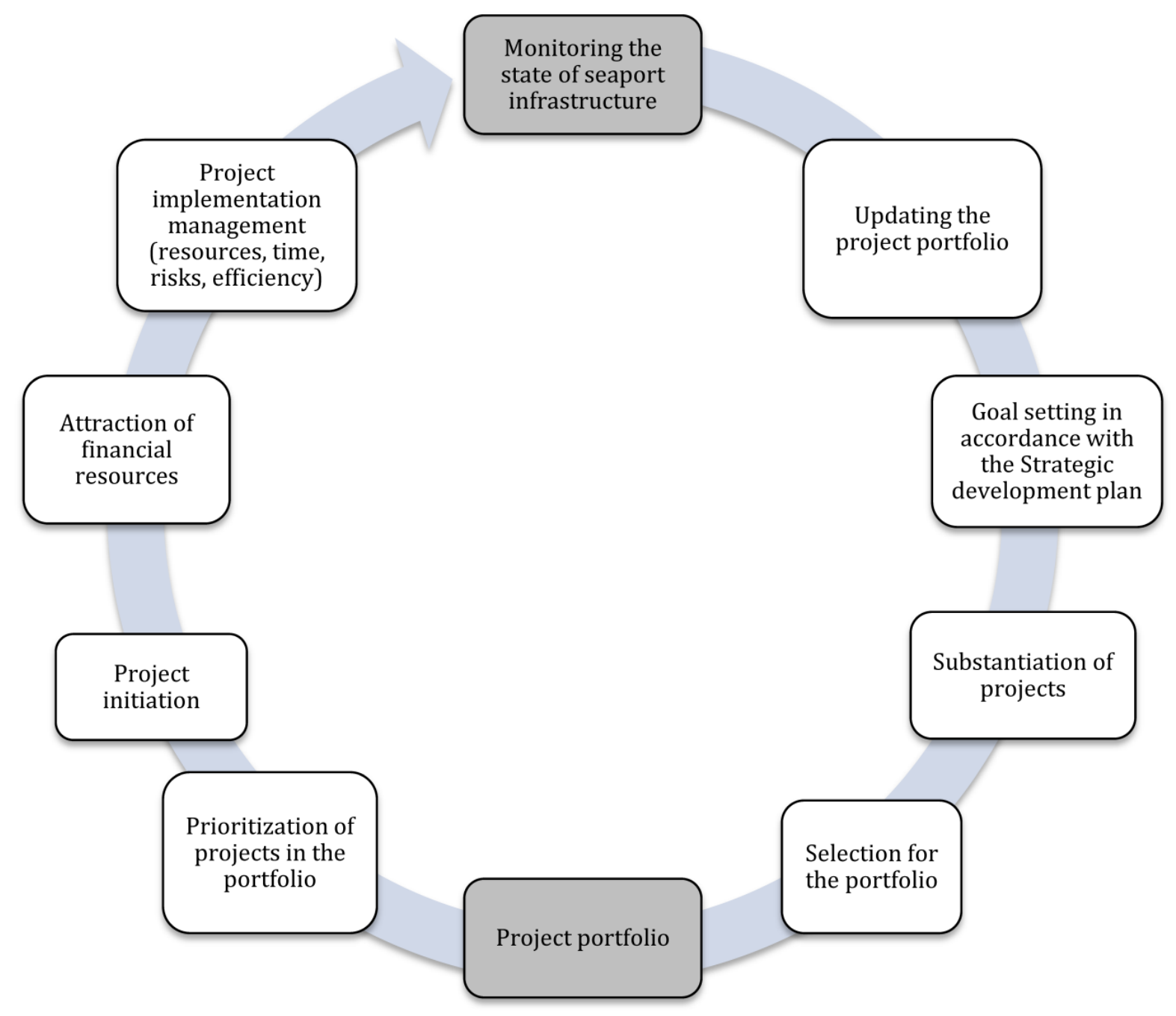

Fig. 2. The sequence of the project approach application to the management of the infrastructure of seaports

The property used in seaport activities may be in state, municipal and private ownership. Modernization, reconstruction and construction of port infrastructure, as written in the Law on Seaports of Ukraine, is carried out on the basis of relevant agreements on behalf of the USPA. As the financing of the USPA activities is carried out at the expense of port fees, which are managed by it in accordance with the Law, fees for services and rent, other sources not prohibited by law, and financing of certain areas, including modernization, repair, reconstruction and construction of waterworks and other port infrastructure facilities, can be carried out at the expense of the State Budget of Ukraine (Table 1), the initiated projects are financed accordingly.

Strategic objects of port infrastructure are not subject to lease or concession (except for berths, piers, shore protection, shore protection 
structures and other types of berth structures, railways and highways) (before the first branch outside the port), utilities, etc.), privatization and / or alienation in any other way. Berths can be leased for up to 49 years. Berths, piers, shore strengthening, shore protection structures and other types of berth structures may be the objects of public-private partnership, including concessions defined by a public-private partnership / concession agreement. Such facilities are transferred to a private partner or concessionaire together with lifting and transport and other equipment that provides loading / unloading and storage of goods and / or passenger service.

Private investment in state-owned port infrastructure facilities on the territory of the seaport is carried out on the basis of concession agreements, joint venture agreements, lease agreements, other types of investment agreements concluded on the basis of special procedures defined by the laws of Ukraine. Investing in strategic port infrastructure may involve repairing, modernization, reconstruction or construction of such facilities.

Table 2

\section{Distribution of participation in project activities at seaport infrastructure facilities}

\begin{tabular}{|l|c|c|}
\hline \multicolumn{1}{|c|}{$\begin{array}{c}\text { Infrastructure } \\
\text { facilities }\end{array}$} & $\begin{array}{c}\text { Capital } \\
\text { investments }\end{array}$ & $\begin{array}{c}\text { Maintenance of } \\
\text { infrastructure } \\
\text { facilities in } \\
\text { operational } \\
\text { condition }\end{array}$ \\
\hline Dredging & State & The USPA \\
\hline $\begin{array}{l}\text { Breakwaters, piers and shore protection } \\
\text { structures }\end{array}$ & State & State \\
\hline $\begin{array}{l}\text { Port infrastructure (underwater } \\
\text { structures, port roads, lighthouses) }\end{array}$ & State & State \\
\hline $\begin{array}{l}\text { Port facilities / sub infrastructure } \\
\text { (administrative buildings, workshops) }\end{array}$ & The USPA & The USPA \\
\hline $\begin{array}{l}\text { Terminals (berths, equipment, cranes, } \\
\text { operating systems, refrigerator systems, } \\
\text { operating rooms) }\end{array}$ & The USPA & The USPA \\
\hline $\begin{array}{l}\text { Communication with inland areas (local } \\
\text { freight depot, railway tracks in the port, } \\
\text { terminal warehouses, connecting roads) }\end{array}$ & \multicolumn{2}{|c|}{} \\
\hline
\end{tabular}


Compensation of investments made by economic entities in port infrastructure strategic objects, which are objects of state property, is carried out on the basis of relevant agreements concluded by the USPA and investors in the manner and under the conditions determined by the Cabinet of Ministers of Ukraine. Sources of compensation for investments in port infrastructure strategic objects may be port dues managed by the administration of seaports of Ukraine, and other sources not prohibited by law.

\section{Modern technological solutions in water engineering. Stress/Strain State of Backfilling Materials in Retaining Structures}

Analysis of the features of the berth front of the country's seaports shows the use of mainly pile-based structures (i.e. bollards made of steel sheet piles of various types and overpasses on reinforced concrete (prismatic) or steel (tubular) piles.

The berth front of Ukraine should be classified as relatively "young", as the average age of berths in the country's ports is 33.7 years, but, for example, the average age of berths is 46.4 years for the ports of the former Soviet Union as a whole. The main number of berths of Ukrainian seaports is characterized by a duration of operation from 20 to 40 years. Most of the berths by 2018 have not depleted the regulations governing the quantitative assessment of physical performance, and therefore its definition is, to some extent, subjective.

Successful development of sea trade ports is impossible without constant engineering and scientific research related to the operation of waterworks and equipment, displacement and deformation of structures, determining the possibility of their further operation in terms of increasing port traffic. An important issue in water engineering is also to determine the feasibility of reconstruction of existing structures or construction of new ones; modernization of existing facilities on the basis of modern innovative technologies. This finds its practical application in the form of development and implementation of relevant innovative projects ${ }^{8,9,10}$.

${ }^{8}$ Крижановська І.П. Інноваційні проекти в гідротехнічному будівництві і можливість застосування геотекстильних матеріалів при реконструкції споруд. Проектний та логістичний менеджмент: нові знання на базі двох методологій. Т. 2 : монографія / І.О. Лапкіна, В.О. Андриєвська, В.Ю. Смрковська, І.П. Крижановська та ін. ; за заг. ред. І.О. Лапкіної. Одеса: КУПРІЄНКО СВ, 2019. C. 190-197. DOI: 10.21893/2616-8936.2019-02.

9 Крижановська І.П. Застосування інноваційних матеріалів в сучасному гідротехнічному будівництві 3 розробкою моделей та методів управління проектами. Розвиток методів проектування, будівництва та реконструкиії 
Backfilling materials (sand, gravel, stones and similar granular construction materials) are often used when erecting various retaining walls, diaphragm walls, sheet pilings, etc. Materials consumption of the structure (and, correspondingly, project's estimate) depends particularly on correct determination and account of stress/strain state of the backfilling materials. As practice confirms, displacements and deformations of the considered structures (or, let say, of its surface contacting with the backfilling) influence on backfilling stress state and on its lateral pressure upon the retaining structure. So, working out and application of the corresponding improved calculation model and the numerical algorithm is actual and may provide a better design solution (more reliable or more economically effective).

2.1. Features of the considered problem. The system "backfilling material -retaining structure" is characterized by the following features: a retaining structure has an arbitrarily inclined contact face (at an angle $\alpha_{0}$ to the vertical) and bottom surface of the homogeneous backfill material (at an angle $\beta$ to the horizon) when a distributed load with an intensity $q$ acts on the latter (Fig. 3). A kinematic model of such system is based only on two premises under conditions of the plane problem ${ }^{11,12}$ :

(1) The character of the stress state at an arbitrary point on the contact between the lateral surface of the structure and backfilling is determined by the ratio of the horizontal displacement $u(z)$ of the structure's cross section to the embedment depth $\mathrm{z}$ of this section with respect to the point of intersection between the surface of backfilling and the retaining wall. The backfilling will be in the sub-limiting state when $\mathrm{u}(\mathrm{z}) / \mathrm{z}<\alpha$, and in the limiting stress state for the inverse ratio. Considering that the condition

гідротехнічних споруд. Ч. 2: Серія монографій / М.П. Дубровський, C.I. Рогачко, С.В. Бугаєва, І.П. Крижановська та ін. ; за ред. М.П. Дубровського. Одеса : Купрієнко С.В., 2020. С. 120-141. DOI: 10.30888/2663-9742.2020-01

10 Kryzhanovskaya I.P. Technological map of development of methods of management innovative projects in hydrotechnical construction. Heutiges Indenieurwesen und innovative Technjijgien. 2018. № 4. Vol. 2. P. 23-27. DOI: 10.30890/2567-52-73. URL: http://www.moderntechno.de/index.php/meit/issue/ view/2018-04-02.

11 ROM 0.2-90. Actions in the design of maritime and harbor works. Maritime Works Recommendations, Ministerio de Obras Publicas y transportes, 1990. Madrid : Puertos del Estado. 264 p. URL: http://www.puertos.es/es-es/BibliotecaV2/ROM\% 200.2-90\%20(EN).pdf.

${ }^{12}$ Doubrovsky M.P. Determination of lateral soil pressure against a retaining wall with allowance for structure kinematics. Основания, фундаменть и механика грунтов. № 2. 1997. Р. 6-9. 
promoting the formation of the backfilling's limiting stress state over. the entire contact face of the structure (with a height $\mathrm{H}$ ) and along its section (over a segment with a height $\mathrm{z}$ ) are analogous, we can assume that $\alpha_{a}=0.001-0.0015$ and $\alpha_{p}=0.01-0.03$ during the development of an active and passive pressure of the backfilling, respectively.

The premise in question is distinguished from the condition normally considered whereby a limiting state characterized by the ratio of the socalled critical displacement of the wall to its height $\mathrm{u}_{\mathrm{cr}} / \mathrm{H}=\alpha$ sets in; this requires appropriate confirmation. Under natural conditions, the process whereby the backfilling material goes over from a state of rest for a stationary wall to the limiting stress state occurs not jump-wise, but smoothly in the displacement interval $\left[0 ; \mathrm{u}_{\mathrm{cr}}\right]$. For current displacements $\mathrm{u}<\mathrm{u}_{\mathrm{cr}}$ (for example, with progressive displacements or displacement combined with rotation about the bottom of the wall), consequently, the part of the backfilling in contact with the wall in its upper part adjacent to the backfilling surface) is in the limiting, and part (in the underlying area of the structure) in the sub-limiting stress state. When it becomes equal to zero (i.e. when $\mathrm{u}=\mathrm{u}_{\mathrm{cr}}$ ), therefore, the ratio $\mathrm{u} / \mathrm{H}$ characterizes not the current, but only the final state, which for some structure, may not set in under small displacements.
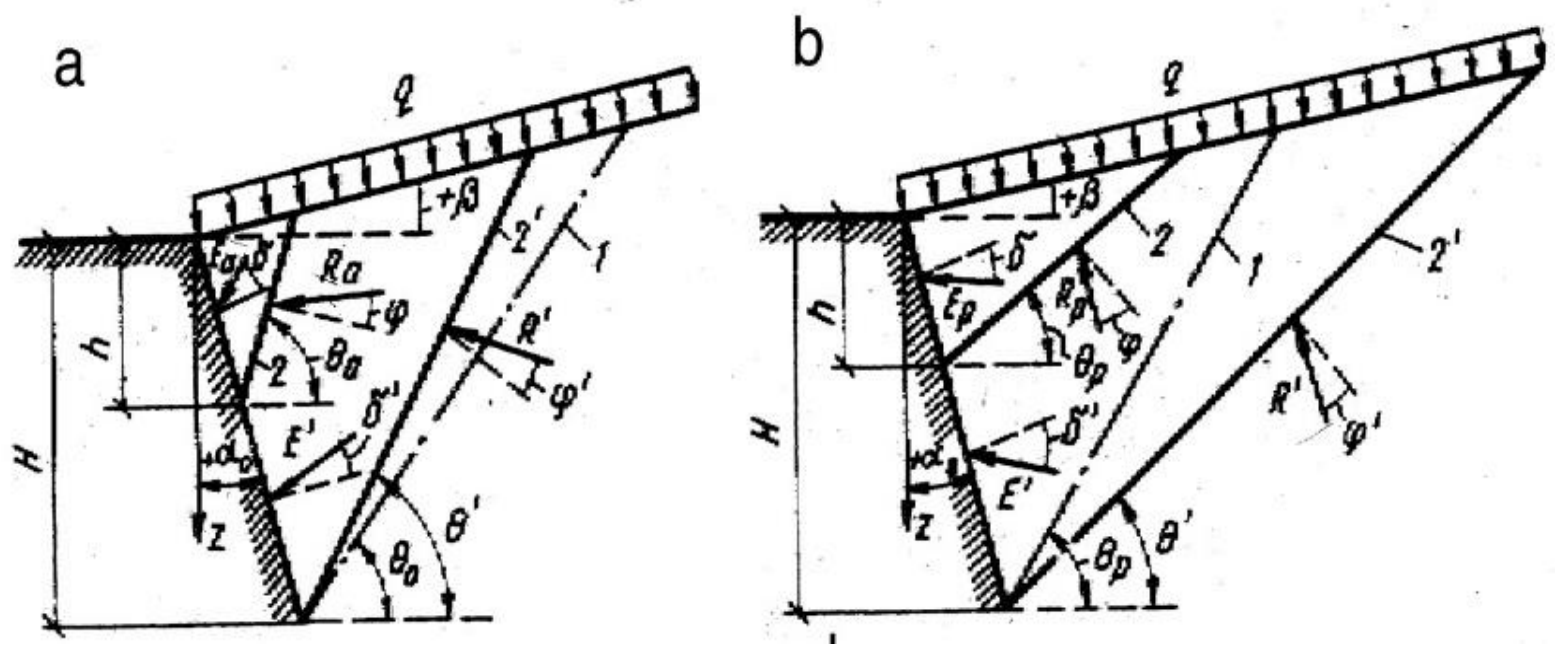

Fig. 3. Statement of the mixed problem of determination of lateral backfilling pressure against retaining structure:

$a$-retaining wall moves away from the backfilling and thrust (active) pressure is formed; $b$-retaining wall moves toward backfilling and reactive pressure is developed; 1 - conditional slip surface corresponding to the pressure of backfilling at the state of rest; 2 and 2'- slip surfaces bounding, respectively, limiting and submitting areas of backfilling material stress state. 
Let us examine the following imaginary experiment to illustrate the logical nature of the premise that we have adopted. Let there be $\mathrm{N}$ similar retaining walls with heights $\mathrm{H}_{1}>\mathrm{H}_{2}>\ldots>\mathrm{H}_{\mathrm{N}}$ for the faces in contact with the backfilling, which are displaced with respect to the backfill soil, for example, forward at the same distance $u$. In that case, let the height $\mathrm{H}_{\mathrm{N}}$ of the N-th wall be such that $\mathrm{u} / \mathrm{H}_{\mathrm{N}} \geq \alpha$, i.e., the backfilling over the entire height of the contact face of the $\mathrm{N}$-th retaining wall goes over to the limiting stress state, and the height of the remaining walls such that $\mathrm{u} / \mathrm{H}_{1}<\alpha ; \mathrm{u} / \mathrm{H}_{2}<\alpha ; \ldots ; \mathrm{u} / \mathrm{H}_{\mathrm{N}}-1<\alpha$, i.e., for the remaining $\mathrm{N}-1$ walls, not all of the backfilling material interacting with their contact faces goes over to the limiting state. If, thereafter, the backfilling within the bounds of the entire height of the N-th wall goes over to the limiting stress state as the wall is displaced by a distance $u$, it is logical to assume that for the same displacement and other walls, the backfilling material within the limits of the same height $\mathrm{H}_{\mathrm{N}}$ (referenced from the surface of the backfill) will be within the limiting stress state, and the backfilling in the lower part of the contact faces of the walls in the sections with a height $\mathrm{H}_{1}-\mathrm{H}_{\mathrm{N}}, \mathrm{H}_{2}-\mathrm{H}_{\mathrm{N}}, \ldots$, $\mathrm{h}_{\mathrm{N}-1}-\mathrm{H}_{\mathrm{N}}$ will be in the sub-limiting stress state. This may be caused, among other things, by the fact that the extent to which deformations develop in the overlying (spilling over immediately beyond the retreating or bulging advancing contact face of the retaining wall), and not the underlying soil is decisive for the formation of the backfilling's stress state at a depth $\mathrm{H}_{\mathrm{N}}$ along the contact face of the i-th retaining wall.

Conversion from a criterion based on the development of a limiting stress state at an arbitrary point on the contact face of a retaining wall in the form of the ratio $\mathrm{u} / \mathrm{H}$ (resulting in jump-wise development of the limiting state simultaneously at all points of the contact face) to a criterion in the form of the ratio $\mathrm{u}(\mathrm{z}) / \mathrm{z}$ (ensuring a gradual conversion of the backfilling to the limiting stress state as the displacements of the structure increase and making it possible to account for the existence and transformation of the zone of the backfilling's limiting stress state) is also motivated by these discussions ${ }^{13}$.

The boundary between the zones of the backfilling's limiting and sublimiting stress states (or height $h$ of the zone of contact between the backfilling material, which is in the limiting state, and the structure) can be found from the condition $\mathrm{u}(\mathrm{h}) / \mathrm{h}=\alpha$, for the use of which the form of $\mathrm{u}(\mathrm{z})$ function, which can be determined by the pattern of the structure's

13 Doubrovsky M.P., Poizner M.B. Marine Engineering and Geotechnique. Odessa : DRUK, 2000. 163 p. 
deformations, should be given (for example, this function is linear for rigid structures, and $\mathrm{u}=\mathrm{const}$ and $\mathrm{h}=\mathrm{u} / \alpha$; for advancing displacements).

(2) The angles of deviation of the resultant reactive pressure of the backfilling material behind the thrust (or reactive) prism from the normal to the boundary of this prism and the resultant lateral pressure of the backfilling from the normal to die contact face of the structure are assumed equal to the angles of the backfilling's internal friction $\varphi$ and the contact friction $\delta=m \varphi(0 \leq m \leq 1)$ for the zone of the limiting stress state with a height $h$, and equal, respectively, to $\varphi$ ' and $\delta$ ' for the zone of the sub-limiting stress state with a height $\mathrm{H}-\mathrm{h}$; in that case:

$$
\varphi^{\prime}=\varphi_{0}+n\left(\varphi-\varphi_{0}\right) ; \delta^{\prime}=\delta_{0}+n\left(\delta-\delta_{0}\right),
$$

where $\mathrm{n}$ is a parameter dependent on the relationship between the dimensions of the zones of the limiting and sub-limiting stress states of the backfilling $(0 \leq \mathrm{n} \leq 1)$ and defined by the ratio $\mathrm{n}=\mathrm{V}_{\mathrm{e}} / \mathrm{V}\left(\mathrm{V}_{\mathrm{e}}\right.$ and $\mathrm{V}$ are, respectively, the volumes of the backfilling prism in the limiting stress state, and all of the backfilling material that interacts with the contact face of the structure, as defined from geometric considerations in conformity with the assumed shape of the slip surface), $\varphi_{0}$ is the conditional angle of internal friction of the backfilling under pressure in the at-rest state (may be determined from known recommendations ${ }^{9-14}$ ), and $\delta_{0}$ is the conditional angle of contact friction under pressure in the at-rest state.

2.2. Solving of the considered problem. The premises adopted are sufficient for the determination of both zones (limiting and sub-limiting) of the stress state in the mass of backfilling material interacting with the structure and for determination of the lateral pressure, which can be found from the side of these zones against the structure. The kinematics model adopted makes it possible to implement any of the premises traditionally employed in soil mechanics for the shape of the slip surface, and the computational relationships for determination of the thrust and reactive pressure are determined by universal equations that are distinguished only by sign in the indicated cases (in further calculations, the upper and lower signs, respectively) before the values of the angles $\varphi$ and $\delta$, or $\varphi^{\prime}$ and $\delta{ }^{\prime 11}$.

The resultant $\mathrm{E}$ of the lateral backfilling pressure against the structure can be defined for each current strain state of the structure as the algebraic sum of its two components: the limiting component $E_{e}$, which acts over a

${ }^{14}$ Doubrovsky M.P., Poizner M.B. Innovative Development of Coastal, Port and Marine Engineering: Structures, Technologies and Design. Saarbrucken, Germany : LAP Lambert Academic Publishing, 2016. 125 p. 
section with a height $h$, and the sub-limiting component $E$ ' which acts over a section with a height $\mathrm{H}-\mathrm{h}$ (Fig. $4 \mathrm{a}$ and $\mathrm{b}$ ) in conformity with the expression:

$$
\vec{E}=\vec{E}_{e}+\vec{E}^{\prime}=\left[E_{e}^{2}+E^{\prime 2}+2 E_{e} E^{\prime} \cos \left(\delta_{e}-\delta^{\prime}\right)\right]^{1 / 2}
$$
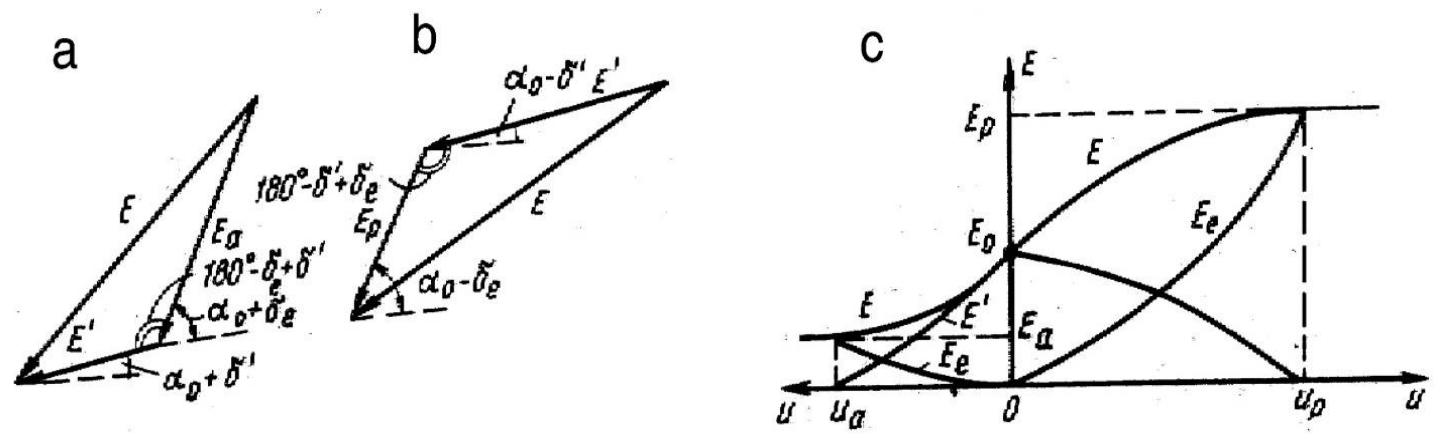

Fig. 4. Determination of the resulting $E$ of lateral backfilling pressure using its limiting Ee and sub-limiting E' components:

$a, b$-addition of force vectors, respectively, under thrust and reactive pressure, $c$-the relationship between lateral backfilling pressure and displacement of structure (EO is lateral backfilling pressure in the at-rest state)

The indicated components of the lateral pressure are found by successive examination of the equilibrium conditions of the limiting and sub-limiting backfilling prisms, the geometry of which is determined by the shape assumed for the slip surface (Fig. 5).

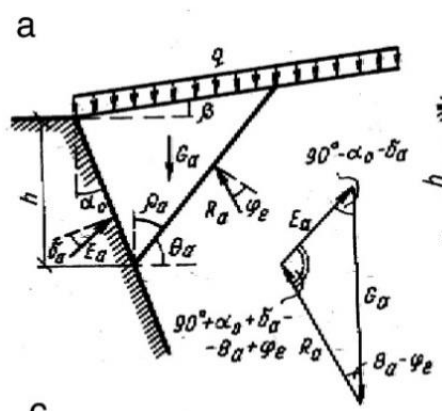

c

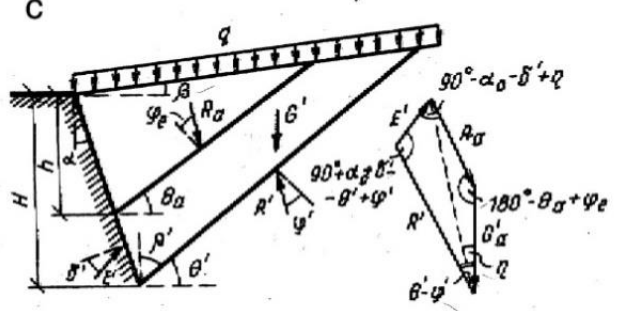

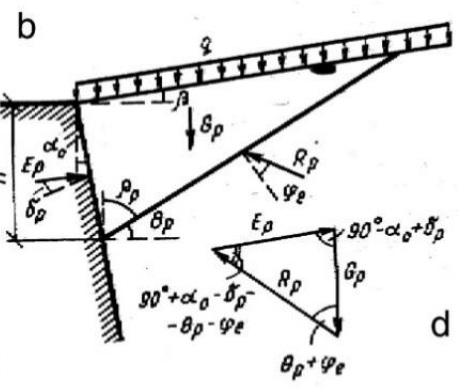

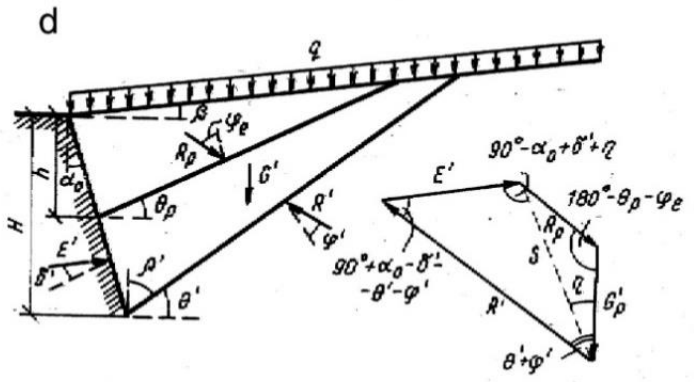

Fig. 5. Determination of backfilling pressure against retain wall with allowance for kinematics of structure:

$a, b$-computational schemes and force polygons for limiting prism under thrust and reactive pressures, respectively;

$c, d$-the same for sub-limiting prism 
From the presented schemes, using the equilibrium condition of the limiting prism (Fig. 5a,b), we obtain:

$$
E_{e}=G_{e} \sin \left(\theta \mp \phi_{e}\right) / \cos \left(\alpha_{0} \pm \delta_{e} \pm \phi_{e}-\theta_{e}\right),
$$

where;

$$
\begin{gathered}
G_{e}=G_{\gamma e}+G_{q e} ; \\
G_{\gamma e}=0.5 \gamma h^{2}\left(\tan \alpha_{0}+\tan \rho_{e}\right)\left(1+\tan \alpha_{0} \operatorname{tg} \beta\right) /\left(1-\tan \rho_{e} \operatorname{tg} \beta\right) ; \\
G_{q e}=q h\left(\tan \alpha_{0}+\tan \rho_{e}\right) /\left(1-\tan \rho_{e} \tan \beta\right) ; \\
\tan \theta_{e}=\left(\cos \alpha_{0} \pm k_{0} \sin \phi_{e}\right) /\left(k_{0} \cos \phi_{e}-\sin \alpha_{0}\right) ; \\
k_{0}=\left\{\left[ \pm \sin \left(\phi_{e}+\delta_{e}\right) \cos \left(\alpha_{0}-\beta\right)\right] /\left[\cos \left(\alpha_{0} \pm \delta_{e}\right) \sin \left( \pm \phi_{e}-\beta\right)\right]\right\}^{1 / 2} ; \\
\rho_{e}=0.5 \pi-\theta_{e} ; \\
R_{e}=G_{e} \cos \left(\alpha_{0} \pm \delta_{e}\right) / \cos \left(\alpha_{0} \pm \delta_{e} \pm \phi_{e}-\theta_{e}\right),
\end{gathered}
$$

here, $\gamma$ is the specific gravity of the backfilling material, and the subscript "e" indicates that the parameters being determined to apply to the extremal (i.e. limiting - active or passive) stress state.

Proceeding then to an analysis of the equilibrium conditions of the sub-limiting prism (Fig. 5c,d), we obtain:

$$
\begin{gathered}
S=\left[R_{e}^{2}+G^{\prime 2}+2 R_{e} G^{\prime} \cos \left(\theta_{e} \mp \phi_{e}\right)\right]^{1 / 2} ; \\
\eta=\arcsin \left[R_{e} \sin \left(\theta_{e} \mp \phi_{e}\right) / S\right] ; \\
G^{\prime}=G_{\gamma}^{\prime}+G_{q}^{\prime} ; \rho^{\prime}=0.5 \pi-\theta^{\prime} ; \\
G_{\gamma}^{\prime}=0.5 \gamma\left(1+\tan \alpha_{0} \tan \beta\right)\left[H^{2} \frac{\tan \alpha_{0}+\tan \rho^{\prime}}{1-\tan \beta \tan \rho^{\prime}}-h^{2} \frac{\tan \alpha_{0}+\tan \rho_{e}}{1-\tan \rho_{e} \tan \beta}\right] ; \\
G_{q}^{\prime}=q\left[H \frac{\tan \alpha_{0}+\tan \rho^{\prime}}{1-\tan \beta \tan \rho^{\prime}}-h \frac{\tan \alpha_{0}+\tan \rho_{e}}{1-\tan \rho_{e} \tan \beta}\right],
\end{gathered}
$$

and the relationships for determination of the angle $\theta^{\prime}$ are similar to Eqs. (3) and (4), if the angles $\varphi$ and $\delta$ in them are replaced by $\varphi^{\prime}$ and $\delta$ '. For calculation of the parameter $n$, we obtain:

$$
n=\frac{h^{2}}{H^{2}} \frac{\cos \left(\theta_{e}-\alpha_{0}\right) \sin \left(\theta^{\prime}-\beta\right)}{\cos \left(\theta^{\prime}-\alpha_{0}\right) \sin \left(\theta_{e}-\beta\right)},
$$


from geometric considerations (see Fig. 4); hence, it is possible to express a function of the form:

$$
y(n)=h^{2} \cos \left(\theta_{e}-\alpha_{0}\right) \sin \left(\theta^{\prime}-\beta\right)-n H^{2} \cos \left(\theta^{\prime}-\alpha_{0}\right) \sin \left(\theta_{e}-\beta\right) .
$$

From the latter, it is also possible to find the desired parameter $n$ by the iteration method (given $\mathrm{n}$ and calculating the angles $\varphi^{\prime}$ and $\delta$ ' from relationships (1)); this is possible when the condition $y(n)=0$ is satisfied.

Determining the height $h$ of the zone of the limiting stress state of the soil and the value of the parameter $\mathrm{n}$ corresponding to it for each increment of the structure's displacement, it is possible to obtain a computational " $\mathrm{E}-\mathrm{u}$ " curve similar to that presented in Fig. $4 \mathrm{c}$ within the range from the active $\left(E_{a}\right)$ to passive $\left(E_{p}\right)$ pressure. It is apparent from the latter, among other things, that the limiting component increases from zero (when there are no displacements) to $E_{a}$ or $E_{p}$ (depending on the direction of the displacements of the contact face of the structure) in the displacement interval under consideration $\left[0 ; \mathrm{u}_{\mathrm{cr}}\right]$, while the sub-limiting component decreases from the at-rest pressure to zero, respectively.

The computational algorithm has been developed for the calculation and plotting of the "E-u"-type curve. The special investigation has indicated a substantially lower effect of the accuracy with which the parameter $\alpha$ is assigned (within the above-adopted intervals of its values) on the computed value of the backfilling's lateral pressure as compared with the accuracy with which the physics-mechanical characteristics of the backfilling material, as determined by traditional means, are assigned.

\section{CONCLUSIONS}

Important and relevant areas of further research aimed at improving and developing the berth front of seaports of Ukraine are

- improvement of methods of design, construction and technical operation of traditional structures of berths adapted to the conditions of operation of deep-water berths;

- development and implementation in the practice of port water engineering construction of new rational design and technological solutions as well as organizational and methodological basics of the project management theory;

- obtained dependencies allow more precise determination of stress state of the backfilling materials due to taking into account either expected (while designing a new retaining structure) or measured (considering existing structure under operation) deformations and displacements. In some cases, it may provide an increase of structure's reliability; in other cases, it may lead to cheaper design/construction solution. 
Further development of the proposed approach may be provided by consideration of non-flat slip surfaces in the backfilling material interacting with the contact surface of the retaining structure.

\section{SUMMARY}

The organizational basics, the current state and prospects of using the project management methodology for the modernization, repair and reconstruction of waterworks have been investigated. The paper considers the formation of the stress/strain state of the backfilling material placed behind the retaining structure with regard to the structure's kinematics. The proposed solution allows determination of the lateral load of the backfilling on the retaining structure in the interval between active and passive pressures in accordance with actual values and directions of the structure's displacements.

\section{REFERENCES}

1. Про схвалення Національної транспортної стратегії України на період до 2030 p. URL: https://zakon.rada.gov.ua/laws/show/4302018-\%D1\%80\#Text.

2. Про затвердження Стратегії розвитку морських портів України на період до 2038 p. URL: https://zakon.rada.gov.ua/laws/ show/548-2013-\%D1\%80\#Text.

3. Про затвердження політики власності державного підприємства «Адміністрація морських портів України». URL: https:// mtu.gov.ua/files/Dok_NORMATUVKA/643.pdf..

4. Закон України «Про морські порти України». URL: https:// zakon.rada.gov.ua/laws/show/4709-17.

5. Про погодження пропозицій щодо реорганізації державних підприємств морського транспорту. URL: https://zakon.rada.gov.ua/ laws/show/133-2013-\%D1\%80.

6. Стратегічний план розвитку АМПУ на період до 2025 p. URL: http://www.uspa.gov.ua/pro-pidpriemstvo/strategichnij-plan-rozvitku.

7. Про затвердження Порядку ведення Реєстру гідротехнічних споруд морських портів України. URL: https://zakon.rada.gov.ua/laws/ show/z0363-13\#n13.

8. Крижановська І.П. Інноваційні проекти в гідротехнічному будівництві і можливість застосування геотекстильних матеріалів при реконструкції споруд. Проектний та логістичний менеджмент: нові знання на базі двох методологій. Т. 2 : монографія / І.О. Лапкіна, В.О. Андриєвська, В.Ю. Смрковська, І.П. Крижановська та ін. ; 
за заг. ред. І.О. Лапкіної. Одеса : КУПРІСНКО СВ, 2019. С. 190-197. DOI: $10.21893 / 2616-8936.2019-02$

9. Крижановська І.П. Застосування інноваційних матеріалів в сучасному гідротехнічному будівництві 3 розробкою моделей та методів управління проектами. Розвиток методів проектування, будівництва та реконструкиії гідротехнічних споруд. Ч. 2 : серія монографій / М.П. Дубровський, С.І. Рогачко, С.В. Бугаєва, І.П. Крижановська та ін. ; за ред. М.П. Дубровського. Одеса : Купрієнко С.В., 2020. C. 120-141. DOI: 10.30888/2663-9742.2020-01.

10. Kryzhanovskaya I.P. Technological map of development of methods of management innovative projects in hydrotechnical construction. Heutiges Indenieurwesen und innovative Technjijgien. 2018. № 4. Vol. 2. P. 23-27. DOI: 10.30890/2567-52-73. URL: http://www.moderntechno.de/ index.php/meit/issue/view/2018-04-02.

11. ROM 0.2-90. Actions in the design of maritime and harbor works. Maritime Works Recommendations, Ministerio de Obras Publicas y transportes, 1990. Madrid : Puertos del Estado. 264 p. URL: http:// www.puertos.es/es-es/BibliotecaV2/ROM\%200.2-90\%20(EN).pdf.

12. Doubrovsky M.P. Determination of lateral soil pressure against a retaining wall with allowance for structure kinematics. Основания, фундаменты и механика грунтов. № 2.1997. Р. 6-9.

13. Doubrovsky M.P., Poizner M.B. Marine Engineering and Geotechnique. Odessa : DRUK, 2000. 163 p.

14. Doubrovsky M.P., Poizner M.B. Innovative Development of Coastal, Portand Marine Engineering: Structures, Technologies and Design. Saarbrucken, Germany : LAP Lambert Academic Publishing, 2016. 125 p.

Information about the authors: Lapkina Inna Oleksandrivna, orcid.org/0000-0001-7468-8993

Doctor of Science (Economics), Professor, Head of Logistic and Project Management Department

Odesa National Maritime University 34, Mechnikova str., Odesa, 65029, Ukraine

Kryzhanovska Iryna Petrivna, Postgraduate Student

Odesa National Maritime University 34, Mechnikova str., Odesa, 65029, Ukraine 